\title{
Effect of grazing by Canada geese Branta canadensis on an intertidal eelgrass Zostera marina meadow
}

\author{
David O. Rivers, Frederick T. Short* \\ Department of Natural Resources, University of New Hampshire, Jackson Estuarine Laboratory, 85 Adams Point Road, \\ Durham, New Hampshire 03824, USA
}

\begin{abstract}
Fishing Island, in Portsmouth Harbor on the Maine-New Hampshire border (USA), is the site of an intertidal eelgrass (Zostera marina L.) bed that is part of SeagrassNet, an international program for long-term seagrass monitoring. Eelgrass bed parameters of canopy height, percent cover, and aboveground biomass have been monitored quarterly since October 2001 using the SeagrassNet protocol. A flock of nearly 100 Canada geese Branta canadensis L. over-wintered at Fishing Island and grazed on eelgrass from January to April 2003, an event that had not been seen at this meadow in 2 decades of observation. Before Canada geese were present, eelgrass parameters demonstrated seasonal fluctuations typical of the region. During the grazing event, eelgrass parameters declined drastically, and biomass losses reached $680 \mathrm{~g} \mathrm{~m}^{-2}$ in parts of the meadow. SeagrassNet data demonstrated that eelgrass did not recover after the geese departed. Additional fieldwork conducted from February to July 2003 showed that eelgrass recruitment via sexual reproduction at Fishing Island was minimal, and vegetative recovery was impeded by Canada goose consumption of the plant meristems. Unlike studies in other locations, which show seagrass quickly rebounding from annual grazing events, eelgrass at Fishing Island showed little recovery from Canada goose grazing through July 2003
\end{abstract}

KEY WORDS: Eelgras $\cdot$ Zostera marina $\cdot$ Grazing $\cdot$ Canada goose $\cdot$ SeagrassNet $\cdot$ Climate change

\section{INTRODUCTION}

Seagrass has long been recognized as an important food resource for migratory waterfowl, whose migration routes often coincide with seagrass meadow locations (Ganter 2000). In North America, eelgrass Zostera marina L. meadows are considered important staging areas for black brant geese Branta nigricans L. on the west coast (Wilson \& Atkinson 1995, Ward et al. 2003, Moore et al. 2004), and for brant B. bernicla L. and Canada geese $B$. canadensis L. on the east coast (Seymour et al. 2002, Hanson 2004). The length of stay of waterfowl at staging areas is often closely correlated to the available seagrass resources at that site (Wilson \& Atkinson 1995). Geese may remain at seagrass meadows for several months during the winter, and goose grazing activity during this time can have a substantial effect on seagrass abundance (Portig et al. 1984, Baldwin \& Lovvorn 1994, Ganter 2000). At European seagrass meadows, waterfowl feeding activity was shown to reduce plant biomass by more than $50 \%$ during the course of the winter grazing period (Jacobs et al. 1981, Nacken \& Reise 2000).

The rate of depletion of vegetation by grazing waterfowl is primarily influenced by the number of birds present at a site and accessibility of the plants (Baldwin \& Lovvorn 1994, Percival et al. 1996, Clausen 2000). Seagrass is accessible to birds in shallow water systems or in intertidal areas (Ganter 2000); changes in water levels due to the tidal cycle can limit the amount of time that food resources are obtainable (Fox 1996, Clausen 2000). Many waterfowl species feed by up- 
ending in the water (Buchsbaum 1987, Vogel 1995), and the length of their neck-plus-head determines the maximum depth at which they can feed (Clausen 2000). In intertidal areas, birds may not be able to reach plants at high tide; feeding is often restricted to low tide when receding water makes the plants accessible (Fox 1996, Percival \& Evans 1997). Observations of brant that congregate in intertidal areas have shown that the birds feed whenever they have access to seagrass, day or night, and rest when plants are inaccessible due to high water levels (Percival \& Evans 1997). Over time, the total seagrass biomass available at a given site declines as the plants are consumed, causing birds to spend a greater amount of time feeding in order to achieve an adequate food intake (Percival et al. 1996, 1998).

Although grazing activity can significantly reduce plant biomass, at many meadows the biomass loss is a short-term effect, and the affected meadows recover during the subsequent growing season (Vermaat \& Verhagen 1996, Nacken \& Reise 2000, Hughes \& Stachowicz 2004). Winter waterfowl grazing coincides with the biomass losses from natural seasonal declines of temperate seagrasses (Short 1992, Ganter 2000). Exclosure studies have demonstrated that patches of seagrass protected from grazing experience biomass declines of up to $65 \%$ during the winter months (Tubbs \& Tubbs 1982, Madsen 1988), indicating a marked seasonality in the plants regardless of grazing. The recovery of seagrass during the summer months re-establishes the food resources such that waterfowl return on a seasonal basis. The dependence of many waterfowl species on recurring seagrass populations has been well documented (Ganter 2000, Moore et al. 2004), and waterfowl have been known to alter their migration routes when seagrass resources become unavailable (Seymour et al. 2002).

In the Great Bay Estuary, on the border of New Hampshire and Maine, USA (see Fig. 1), Canada geese are the most common over-wintering waterfowl species (Vogel 1995). Canada geese that over-winter in this region rely on a few primary food sources, including upland agricultural fields, golf course grasses, coastal and estuarine salt marshes, and eelgrass meadows (Vogel 1995). Within the Great Bay Estuary, the most extensive eelgrass meadows occur in Great Bay itself, with smaller meadows throughout the rest of the estuary and along the coast. This study was conducted at the Fishing Island eelgrass meadow, located near the mouth of the estuary. The Fishing Island meadow is a SeagrassNet site, which is part of an international long-term seagrass monitoring program (Short et al. 2002). Documented cases of eelgrass decline due to Canada goose grazing are rare (Hanson 2004), and studies focusing on other waterfowl species often discuss how seagrass availability affects bird populations while ignoring the process of eelgrass recovery (Ganter 2002, Moore et al. 2004). Our study presents comparative data of eelgrass parameters before, during, and after a Canada goose grazing event and examines eelgrass recovery postimpact. The objectives of this study were to compare bed characteristics of Zostera marina between a year when grazing occurred and a year when no grazing occurred at a long-term monitoring site, and to quantify the extent of eelgrass vegetative and sexual reproduction in the growing season after the grazing event to assess plant re-establishment.

\section{MATERIALS AND METHODS}

The 10 ha Fishing Island eelgrass meadow is located at the mouth of the Piscataqua River in the Great Bay Estuary, on the border of New Hampshire and Maine, USA $\left(43^{\circ} 04.57^{\prime} \mathrm{N}, 70^{\circ} 41.89^{\prime} \mathrm{W}\right.$; Fig. 1). The water depth at this site ranges from 0 to $0.5 \mathrm{~m}$ at low tide and 3 to $4 \mathrm{~m}$ at high tide. Water temperature ranges from
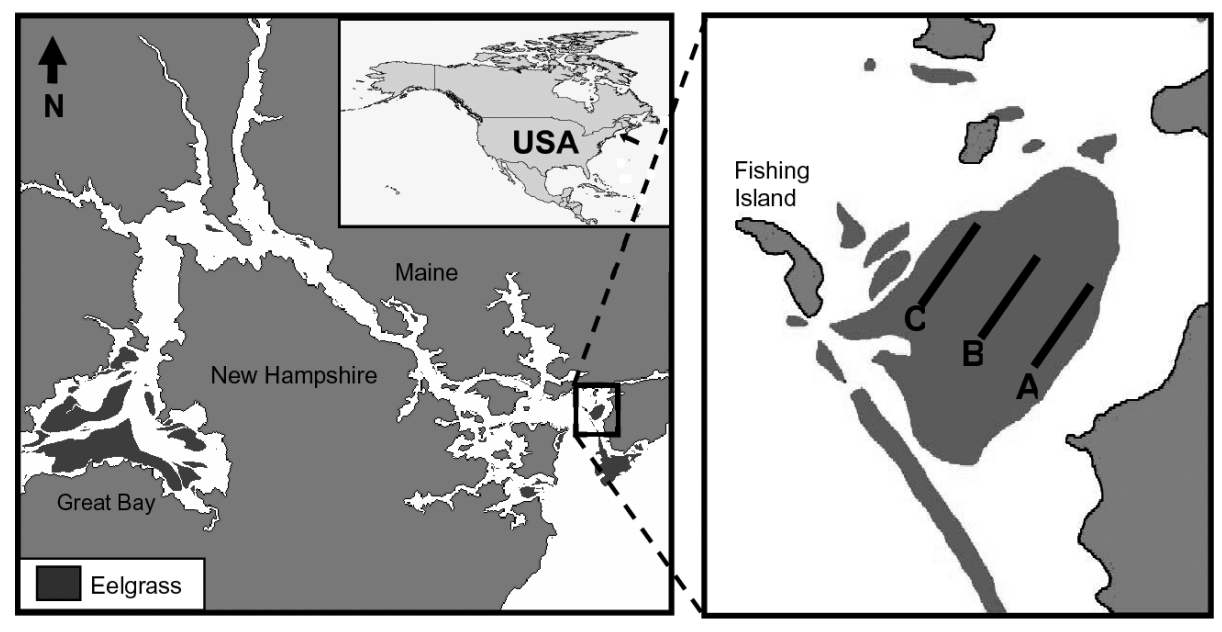

Fig. 1 Great Bay Estuary, on the border of New Hampshire and Maine, USA, and the Fishing Island eelgrass meadow with SeagrassNet transects (Transects A, B and C). Eelgrass coverage is based on near-vertical aerial photography taken in August 2002 
1.0 to $19.0^{\circ} \mathrm{C}$, and salinity ranges from 25 to $34 \mathrm{PSU}$ (Short 1992). Eelgrass at this site shows seasonal fluctuations in growth (Gaeckle \& Short 2002) and biomass (Burdick et al. 1993), with peak biomass levels occurring in September and the lowest levels occurring in February. Change analysis of the eelgrass meadows in the Great Bay Estuary was made based on near-vertical aerial photography (Short \& Burdick 1996).

SeagrassNet is a seagrass monitoring program with sites throughout the world (www.SeagrassNet.org; Short et al. 2002). At each site, field sampling occurs along 3 permanent transects, situated inshore (Transect A), in the middle of the meadow (Transect B), and at the outer edge of the meadow (Transect $C_{\text {; }}$ Fig. 1). Located along each transect are 12 permanent but randomly selected $0.25 \mathrm{~m}^{2}$ quadrats from which data are collected following the SeagrassNet protocol (Short et al. 2002). Percent cover of eelgrass within each quadrat is recorded, and canopy height at each quadrat is determined from the average height of 3 shoots. Biomass samples are collected from a $0.0035 \mathrm{~m}^{2}$ core taken from an area of similar cover more than $0.5 \mathrm{~m}$ shoreward outside of each quadrat; plants are dried at $60^{\circ} \mathrm{C}$ for $48 \mathrm{~h}$ to obtain dry weight. Monitoring occurs quarterly (January, April, July, and October). SeagrassNet data collected at Fishing Island were used to compare bed characteristics of eelgrass between a year when no waterfowl grazing occurred and a year when Canada geese over-wintered. Specifically, eelgrass canopy height, percent cover, and aboveground biomass from October 2001 through July 2003 were measured for this study.

Temperature, light, and salinity at the Fishing Island meadow were also monitored as part of the SeagrassNet protocol. Temperature data were collected using Onset TidbiT temperature sensors, which were placed on the meadow surface at Transect $\mathrm{C}$ and set to record at hourly intervals. Temperature sensors were collected after 6 to $31 \mathrm{~d}$ of recording. Light data were measured using 2 Onset Hobo light sensors placed on the meadow surface at Transects $\mathrm{A}$ and $\mathrm{C}$. The Hobo sensors recorded light (lumens $\mathrm{ft}^{-2}$ ) at 12:00 h for $10 \mathrm{~d}$ prior to SeagrassNet sampling. Salinity was measured at each transect on an incoming tide immediately after SeagrassNet sampling. Average values of temperature, light, and salinity were calculated for each sampling period.

In February, April, and July 2003, an additional field assessment was conducted to further capture the effects of Canada goose grazing activity at Fishing Island. The grazing study was conducted at an area of the eelgrass meadow adjacent to Transect B of SeagrassNet. In February 2003, six $0.0625 \mathrm{~m}^{2}$ quadrats were haphazardly placed such that they all contained at least 1 eelgrass shoot. Quadrats were positioned between 5 and $10 \mathrm{~m}$ apart, and the exact locations were recorded using a Global Positioning System. Quadrats were numbered according to their location, and measurements of shoot density, canopy height, and number of seedlings present within the quadrats were recorded. Finally, each quadrat was excavated to a depth of $10 \mathrm{~cm}$, and the collected sediment and all associated plant material were placed in plastic bags. Excavated samples were transported to the Jackson Estuarine Laboratory for further analysis. In both April and July 2003, each of the 6 previous excavation sites was located, and new $0.0625 \mathrm{~m}^{2}$ quadrats were haphazardly placed near the previous sites and sampled as above.

In the laboratory, each sediment sample was placed in a bag with $2.0 \mathrm{~mm}^{2}$ mesh, and the sediment was rinsed away using seawater. The rinsed samples were stored at $5^{\circ} \mathrm{C}$ and processed within $10 \mathrm{~d}$ of collection. The plant material was sorted into shoots, roots, rhizomes, and seeds. Eelgrass detritus and any non-eelgrass material were discarded. The number of terminal shoots, which grow directly from the end of the main rhizome segment, and lateral shoots, which grow from the end of branching rhizome segments, was recorded, as well as the number of each type of shoot (terminal, lateral) that showed evidence of grazing. Grazed shoots were defined, based on field observations, as shoots with leaves torn off near the sheath, or as shoots with the leaves, sheath, and meristem missing from the end of the rhizome. The total length of the rhizome was measured. The terminal shoots, lateral shoots, rhizomes, and roots for each site were dried at $60^{\circ} \mathrm{C}$ for $48 \mathrm{~h}$ to obtain biomass.

Change analysis was used to compare eelgrass meadow percent cover between the Fishing Island meadow and meadows in Great Bay from 2002 to 2003. The Fishing Island SeagrassNet data were analyzed using a repeated-measures analysis of variance (ANOVA), with quadrats as subjects, transect as a within-subject factor, and sampling date as an amongsubject factor (Zar 1999). Multiple comparisons were performed among transects and sampling dates using a Tukey's honestly significant difference (HSD) test. Canopy height and aboveground biomass data were log transformed before analysis, and percent cover data were logit transformed to produce homogeneous variance. SeagrassNet environmental data (salinity, temperature, light) and eelgrass parameter data measured during February, April, and July 2003 field sampling were analyzed using a 1-way ANOVA. A residual analysis was performed for each parameter, and where necessary, raw data were log transformed prior to analysis (Zar 1999). For all 1-way ANOVAs, multiple comparisons among sampling dates were performed using a Tukey's HSD test. 


\section{RESULTS}

The repeated-measures ANOVA showed significant interactions between transect and sampling date for all eelgrass parameters monitored by SeagrassNet (canopy height $F_{14,231}=13.08, \mathrm{p}<0.001$; percent cover $F_{14,231}=8.54, \mathrm{p}<0.001 ;$ aboveground biomass $F_{14,231}=$ $6.42, \mathrm{p}<0.001)$. Although significant interactions were detected, comparisons made between transects did not show a consistent pattern, and only comparisons within each transect over time are shown (Table 1). Although the SeagrassNet data were analyzed as a complete dataset, for presentation, the results are separated into 1 yr blocks. During Year 1 (October 2001 through July 2002), no Canada geese were observed at the Fishing Island eelgrass meadow, and eelgrass shoots examined during this time showed no evidence of having been grazed. Year 2 of SeagrassNet monitoring (October 2002 through July 2003) includes a winter when Canada geese were actively grazing on eelgrass at the Fishing Island meadow. Canada geese were first sighted during the January 2003 monitoring effort, when a flock of nearly 100 geese was observed. Similar numbers of geese were seen in February and March 2003. The geese left the meadow in early April 2003 and no further sightings occurred during the course of the study.

During Year 1, eelgrass canopy height and aboveground biomass showed similar seasonal fluctuations at all 3 transects, with low values occurring in January and peak values occurring in July (Fig. 2). The same seasonal fluctuations appeared in the percent cover data, with the exception of Transect B, where low percent cover occurred in April. Throughout Year 1, eelgrass canopy height and aboveground biomass were consistently lowest at Transect A and highest at Transect B (Table 1).

In Year 2, all eelgrass parameters declined from October to January, and parameters continued to decline into April 2003 (Table 1). Eelgrass shoots showing evidence of grazing were abundant at the meadow during SeagrassNet sampling in January and April 2003. Between April and July of Year 2, eelgrass percent cover did not change at any of the transects, and only Transect A showed a slight increase in aboveground biomass.

By the end of January in Year 2, eelgrass aboveground biomass at Transects B and C was significantly lower than the January levels of Year 1 (Table 1). In April and July of Year 2, all 3 transects had significantly lower values for eelgrass percent cover, canopy height, and aboveground biomass compared to the same sampling periods in Year 1. Transect B showed the largest overall declines in eelgrass parameters, declining from $98 \%$ cover and $685 \mathrm{~g} \mathrm{~m}^{-2}$ aboveground

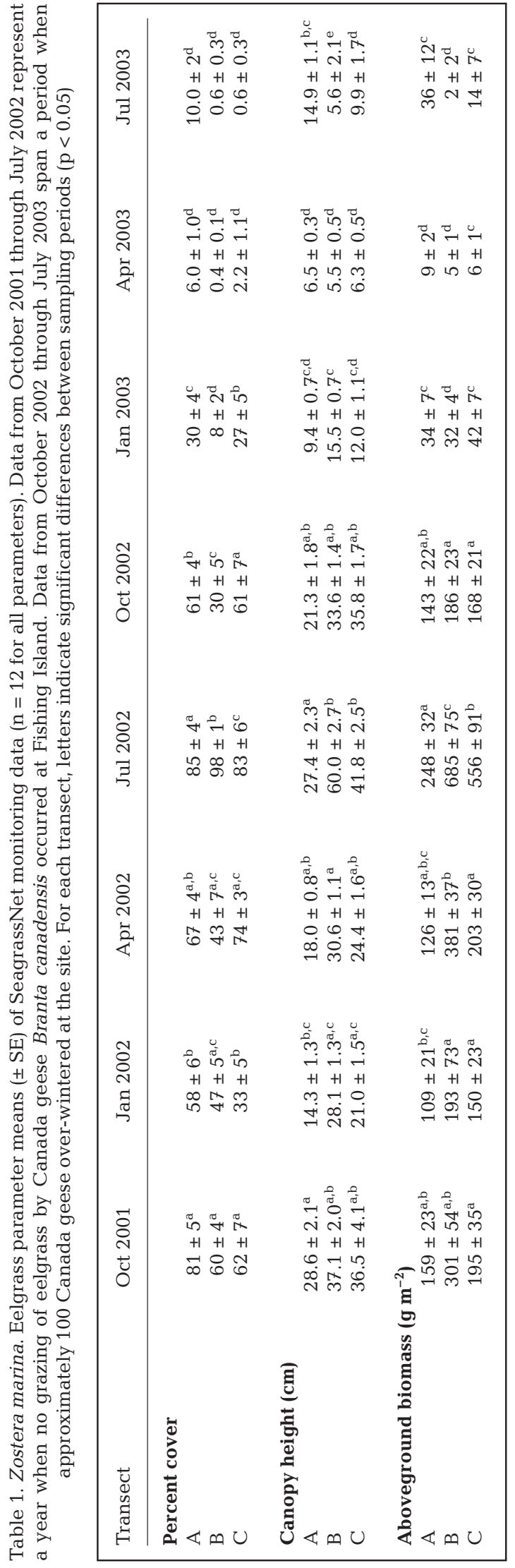



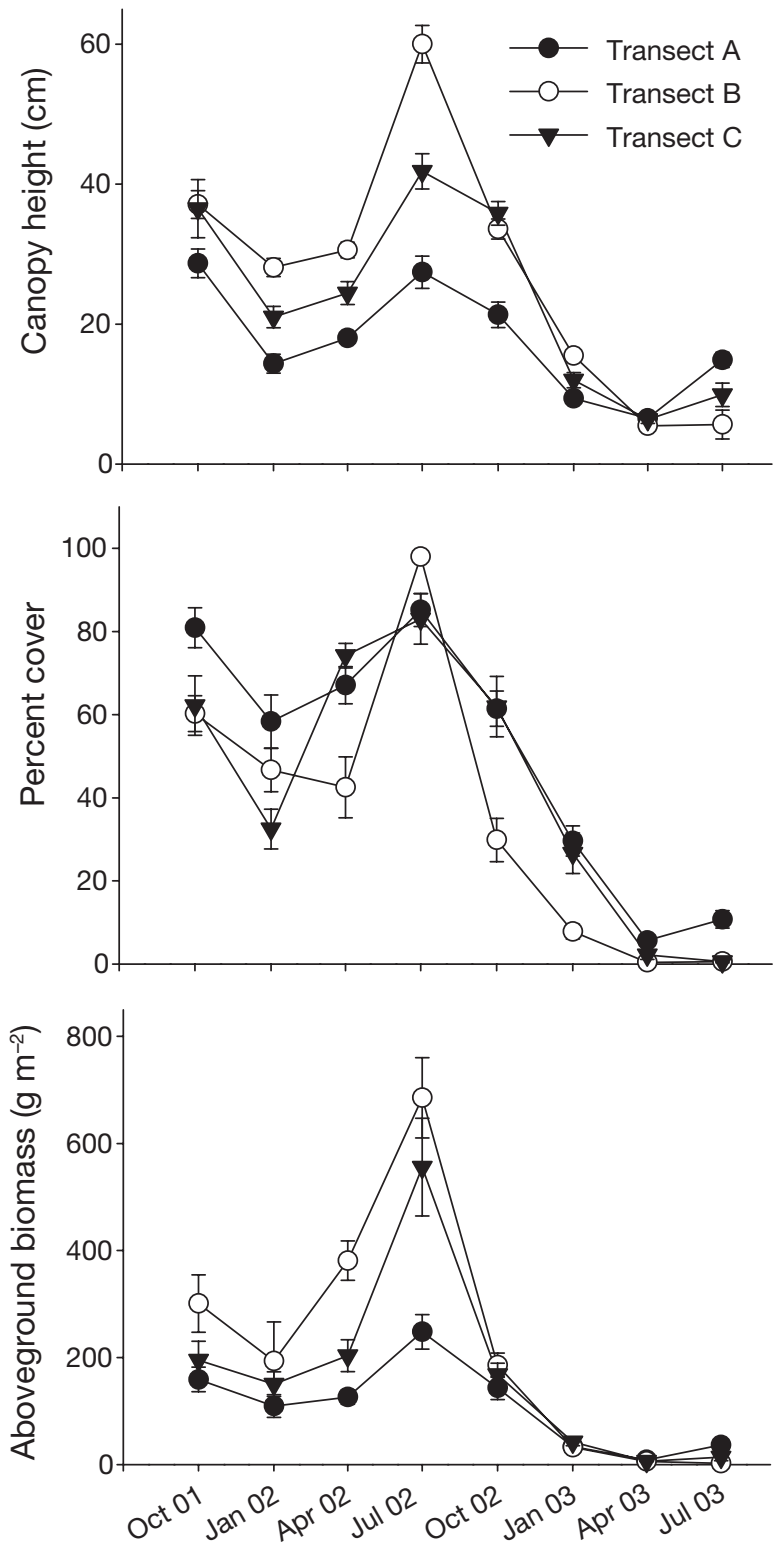

Fig. 2. Zostera marina. Seasonal changes in eelgrass parameters (mean $\pm \mathrm{SE}, \mathrm{n}=12$ ) measured by SeagrassNet monitoring for Transects A, B, and C. Year 1 (October 2001 through July 2002) represents a year when no grazing of eelgrass by Canada geese occurred at Fishing Island. Year 2 (October 2002 through July 2003) spans the season when approximately 100 Canada geese over-wintered at Fishing Island. Significant differences between sampling periods are listed in Table 1

biomass in July of Year 1 to $<1 \%$ cover and $2 \mathrm{~g} \mathrm{~m}^{-2}$ aboveground biomass in July of Year 2.

Further evidence for the decline in eelgrass percent cover was obtained through the analysis of aerial photographs of Fishing Island. Two decades of annual aerial photography of the meadow showed that the eelgrass at Fishing Island had historically high percent cover (F. T. Short unpubl. data). The aerial photographs revealed that the first clear decline in eelgrass percent cover occurred between Years 1 and 2 of our study (Fig. 3).

Environmental parameters at Fishing Island did not fall outside expected ranges in either Year 1 or Year 2 (Fig. 4) for the Great Bay Estuary (Short 1992). A 1-way ANOVA showed a significant effect of sampling date for all parameters (salinity $F_{6,13}=9.76, \mathrm{p}<0.001$; temperature $F_{7,4695}=4778.00, \mathrm{p}<0.001$; light $F_{7,72}=$ 11.54, $\mathrm{p}<0.001$ ). Temperature at the meadow surface showed a seasonal fluctuation in both years, with average winter temperatures lower in Year 2 than in Year 1 $(p<0.05)$. Average salinities were not significantly different between the same months in Years 1 and $2(\mathrm{p}>$ 0.05), and salinities never fell below 24 PSU. Average light reaching the meadow surface was not different $(p>0.05)$ among sampling dates, with the exception of July 2003, which had significantly higher average light than the other dates $(\mathrm{p}<0.05)$.

In February 2003, a month after Canada geese were first sighted at the meadow, there was a higher shoot density of lateral shoots $\left(68\right.$ shoots $\mathrm{m}^{-2}$ ) than terminal shoots $\left(17\right.$ shoots $\left.\mathrm{m}^{-2}\right)$; a greater proportion of terminal shoots showed evidence of having been grazed (Table 2). Eelgrass shoot density decreased from February to April 2003 while geese were active at the Fishing Island site, and by April 2003, the proportion of grazed lateral shoots had increased to $60 \%$. By July 2003, after Canada geese had left the meadow, no terminal shoots remained, and the only evidence of grazing appeared on a few lateral shoots (Table 2). For the majority of grazed shoots examined during this study, the meristem was completely removed by the geese. In only a few cases did the plants have missing leaves but an intact meristem.

Eelgrass rhizome weight declined from $15.4 \mathrm{~g} \mathrm{~m}^{-2}$ in February 2003 to $9.0 \mathrm{~g} \mathrm{~m}^{-2}$ in April 2003, and did not change from April to July (Table 3). Root biomass demonstrated a similar pattern of decline, from $8.6 \mathrm{~g}$ $\mathrm{m}^{-2}$ in February to $7.3 \mathrm{~g} \mathrm{~m}^{-2}$ in April, and showed no change from April to July 2003. Eelgrass rhizome length did not change from February to April 2003, but declined to a low of $854 \mathrm{~cm} \mathrm{~m}^{-2}$ by July 2003 .

\section{DISCUSSION}

Historical monitoring of both eelgrass and waterfowl at Fishing Island showed no evidence of the eelgrass meadow being grazed prior to January 2003. Aerial waterfowl surveys of the Great Bay Estuary conducted annually since 1985 show that Canada geese typically over-winter on the extensive Great Bay eelgrass meadows, and no geese have been sighted over-wintering at 

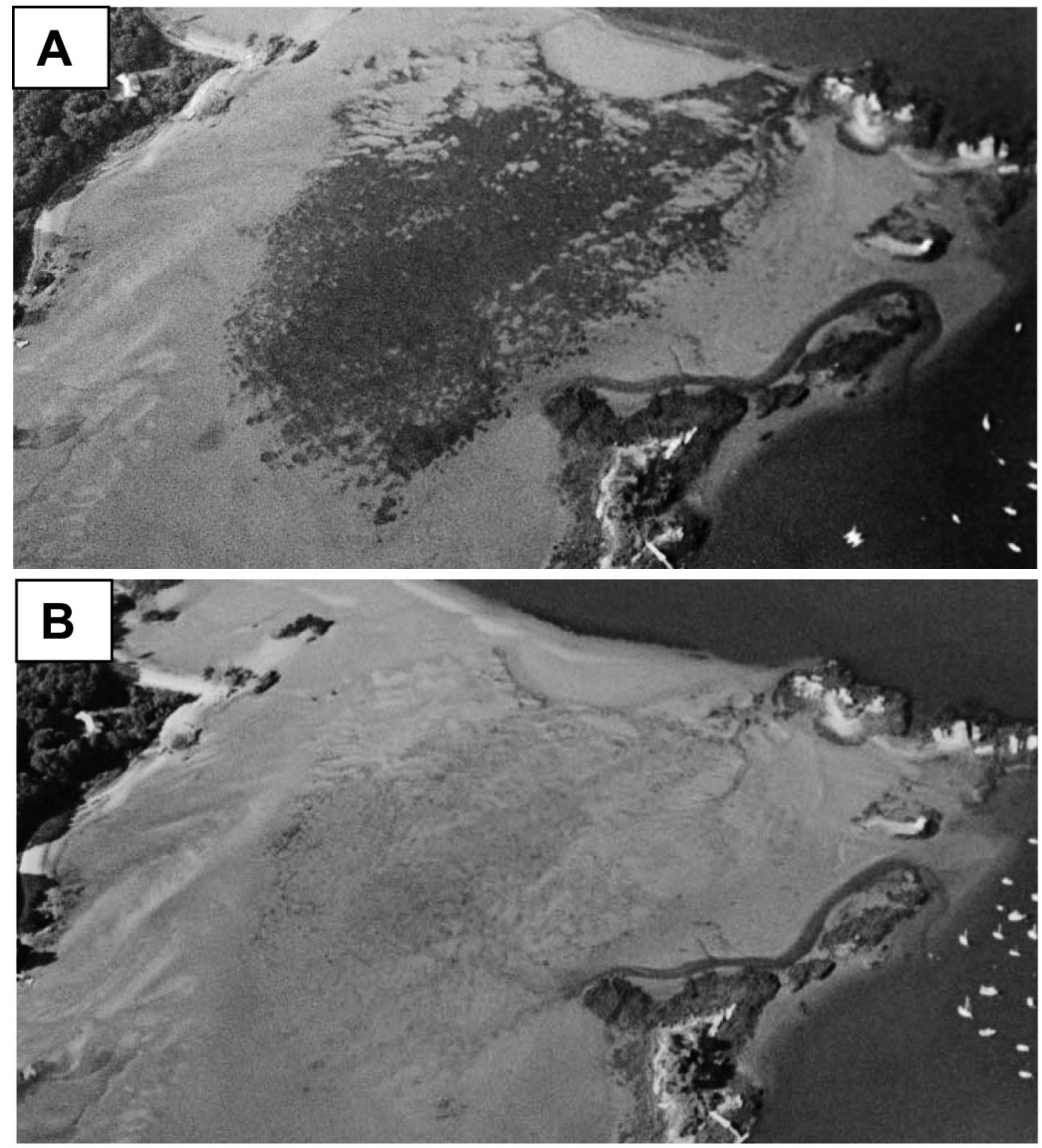

Fig. 3. Zostera marina. Aerial photographs of the Fishing Island eelgrass meadow, from (A) August 2001 and (B) August 2002. The dark area on the mudflat is the eelgrass

Fishing Island (Vogel 1995, B. Smith pers. comm.). Canada geese were first sighted at the Fishing Island meadow during the January 2003 SeagrassNet monitoring effort. Annual aerial photography of the Great Bay Estuary revealed no evidence of eelgrass decline at Fishing Island until 2003. In the Great Bay Estuary region, inland agricultural fields provide the most abundant food resources for over-wintering Canada geese (Vogel 1995). The winter of 2003 was unusually cold, and inland agricultural fields were covered by almost $1 \mathrm{~m}$ of snow. Great Bay itself was frozen over for part of the winter. The continuous snow cover and cold made usual food resources inaccessible and may have forced Canada geese toward the coast to feed. During the winter and spring of 2003, Canada geese fed at Fishing Island from January through April. Dramatic evidence of the effects of goose grazing is seen by comparing the aerial photographs from 2002 and 2003 (Fig. 2).

The Fishing Island site is the only coastal intertidal eelgrass meadow in the Great Bay Estuary, but many other intertidal eelgrass flats occur at the upper end of the estuary in Great Bay itself. However, in Year 2, which was colder (Fig. 4) and had more ice cover than Year 1, geese apparently fed more at Fishing Island, as it was not frozen over and remained accessible throughout the winter. Aerial photography (F. T. Short unpubl. data) shows that the large intertidal eelgrass meadows in Great Bay (Fig. 1) did not change substantially from Year 1 to Year 2.

Eelgrass in the Great Bay Estuary has a cyclical growth pattern, with peak growth occurring in late summer and the lowest growth occurring in midwinter (Short et al. 1989), a pattern that has been confirmed for the Fishing Island meadow (Gaeckle \& Short 2002). Eelgrass parameters from Year 1 of this study displayed the expected seasonal growth pattern and provide a baseline for comparison with Year 2, when Canada goose grazing activity was prevalent throughout the winter and spring. Eelgrass data from Year 2 did not conform to the typical seasonality seen in Year 1, and instead showed severe declines. Changes in environmental factors are often responsible for seagrass loss, but no dramatic changes in temperature, salinity, or light were observed at the Fishing Island meadow between Years 1 and 2 (Fig. 4). The lower average temperatures in Year 2 are not atypical for the region, and the lower average salinity did not fall beneath typical eelgrass bed salinity levels

Table 2. Zostera marina. Eelgrass shoot density, seedling density, seed density, and percentage of grazed shoots at Fishing Island from February to July 2003 (means \pm SE, $n=6$ ). Letters indicate significant differences between sampling periods $(p<0.05)$

\begin{tabular}{|lcccccc|}
\hline & $\begin{array}{c}\text { Terminal shoot } \\
\left.\text { density (shoots } \mathrm{m}^{-2}\right)\end{array}$ & $\begin{array}{c}\text { Grazed terminal } \\
\text { shoots }(\%)\end{array}$ & $\begin{array}{c}\text { Lateral } \\
\text { shoot density }\end{array}$ & $\begin{array}{c}\text { Grazed lateral } \\
\left.\text { shoots (shoots }{ }^{-2}\right)\end{array}$ & $\begin{array}{c}\text { Seeds m } \\
(\%)\end{array}$ & $\begin{array}{c}\text { Seedlings } \\
\mathrm{m}^{-2}\end{array}$ \\
\hline Feb & $17 \pm 3^{\mathrm{a}}$ & 56 & $68 \pm 7^{\mathrm{a}}$ & 26 & $7 \pm 4^{\mathrm{a}}$ & 0 \\
Apr & $1 \pm 1^{\mathrm{b}}$ & 50 & $7 \pm 1^{\mathrm{b}}$ & 60 & $5 \pm 1^{\mathrm{a}}$ & 0 \\
Jul & $5 \pm 2^{\mathrm{b}}$ & 0 & $10 \pm 4^{\mathrm{b}}$ & 7 & $1 \pm 1^{\mathrm{a}}$ & 0 \\
\hline
\end{tabular}




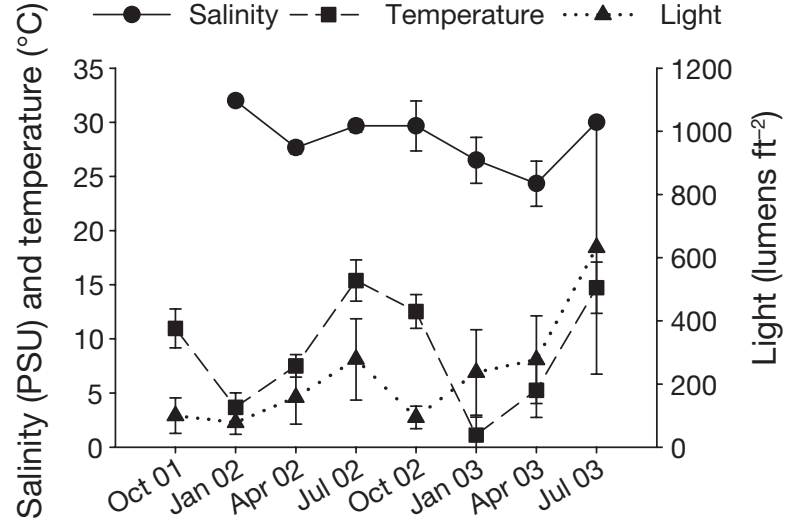

Fig. 4. Change in environmental parameters measured during SeagrassNet monitoring (mean $\pm \mathrm{SD}$ ). Data points show salinity $(\mathrm{n}=3)$, temperature (n ranges from 144 to 745 ) and light $(\mathrm{n}=10)$

Table 3. Zostera marina. Eelgrass belowground parameters at Fishing Island from February to July 2003 (means \pm SE, $n=6$ ). Letters indicate significant differences between sampling periods $(p<0.05)$

\begin{tabular}{|lrrr|}
\hline & $\begin{array}{c}\text { Rhizome } \\
\text { length } \\
\left(\mathrm{cm} \mathrm{m}^{-2}\right)\end{array}$ & $\begin{array}{c}\text { Rhizome } \\
\text { weight } \\
\left(\mathrm{g} \mathrm{m}^{-2}\right)\end{array}$ & $\begin{array}{c}\text { Root } \\
\text { weight } \\
\left(\mathrm{g} \mathrm{m}^{-2}\right)\end{array}$ \\
\hline Feb & $1757 \pm 165^{\mathrm{a}}$ & $15.4 \pm 1.6^{\mathrm{a}}$ & $8.6 \pm 2.3^{\mathrm{a}}$ \\
Apr & $1510 \pm 272^{\mathrm{a}}$ & $9.0 \pm 1.1^{\mathrm{b}}$ & $7.3 \pm 1.1^{\mathrm{b}}$ \\
Jul & $854 \pm 175^{\mathrm{b}}$ & $5.2 \pm 1.3^{\mathrm{b}}$ & $3.5 \pm 1.1^{\mathrm{b}}$ \\
\hline
\end{tabular}

(Pinnerup 1980). The only detectable difference in light reaching the meadow was an increase in light that occurred after Canada geese had left the site. The goose grazing activity at Fishing Island from January 2003 to April 2003 caused a major decline in eelgrass plant parameters, and eelgrass indicators remained low through July 2003.

Although the entire Fishing Island meadow was greatly affected by the grazing event, the most heavily grazed area of the meadow was Transect B, which lost over $680 \mathrm{~g} \mathrm{~m}^{-2}$ of eelgrass aboveground biomass by July 2003, followed by Transect C, which lost over $540 \mathrm{~g} \mathrm{~m}^{-2}$. These transects had the greatest initial eelgrass biomass, and geese likely spent the greatest amount of time feeding at these areas. At a European Zostera noltii meadow, brant spent the majority of their time within $100 \mathrm{~m}$ of the low tide line, as shown in a spatial depletion model developed by Percival et al. (1996, 1998). At the Fishing Island meadow, Transects $\mathrm{B}$ and $\mathrm{C}$ are closest to the low tide line, and Canada geese may have similarly concentrated their feeding efforts at these locations. The greater initial biomass at Transects B and C, in combination with the increased grazing time by Canada geese, would have caused the rate of eelgrass depletion at these areas to be greater than at the inshore portion of the meadow (Transect A).

By consuming eelgrass aboveground biomass during the grazing event, Canada geese had an indirect effect on eelgrass belowground biomass. Separation of aboveground biomass quickly leads to senescence of the belowground plant parts (Kenworthy \& Thayer 1984). At Fishing Island, rhizome weight and root weight declined quickly with the loss of aboveground biomass (Table 3), suggesting a loss of stored carbon typical for decaying plant material (Kenworthy \& Thayer 1984). Although rhizome weight dropped rapidly, rhizome length did not significantly decline until 3 mo after geese had left the meadow (Table 3). The delay between the decline in rhizome weight and complete decay of the rhizome structure has also been observed in seagrass decomposition studies (Kenworthy \& Thayer 1984).

The patterns of eelgrass decline at the Fishing Island meadow indicate that Canada geese may have been selecting eelgrass for consumption based on shoot size. Eelgrass terminal shoots are larger than lateral shoots (Bak 1980), and if geese select shoots based on size, terminal shoots would be consumed preferentially. Before Canada geese arrived at Fishing Island, the eelgrass at the site exhibited growth characteristics typical of a healthy meadow, with a higher proportion of lateral shoots than terminal shoots (Bak 1980). In February 2003, eelgrass terminal shoots were preferentially grazed even though lateral shoot density was higher. Canada geese selected the larger terminal shoots while they were still available, but by April 2003 there were almost no terminal shoots left in the meadow, and goose grazing activity on lateral shoots increased accordingly. The overall changes in eelgrass parameters during the course of the grazing event (Table 2) suggest that Canada geese preferred to graze in areas where eelgrass was larger and more abundant.

Several studies concerning waterfowl grazing activity on seagrass have reported 'giving-up thresholds,' i.e. the seagrass biomass level $\left(\mathrm{g} \mathrm{m}^{-2}\right)$ at which waterfowl leave a meadow after depleting food resources (Percival \& Evans 1997, Clausen 2000). Most of the studies reporting giving-up thresholds concern brant grazing at European Zostera noltii meadows. For our study, we used the April 2003 aboveground biomass as an estimated giving-up threshold, since April was the last month that Canada geese were observed at Fishing Island. The giving-up threshold for our study falls within the range of values listed for brant (Table 4).

After Canada geese left the site, we continued monitoring eelgrass parameters through July 2003 to determine the extent of eelgrass recovery after the grazing event. Although aboveground biomass 
Table 4. Branta canadensis. Estimated giving-up thresholds (see 'Discussion') for waterfowl grazing on seagrass meadows. Studies conducted at European sites concern brant Branta bernicla L. grazing on dwarf eelgrass Zostera noltii $\mathrm{H}$. The giving-up threshold for our study is the April 2003 aboveground biomass, as April was the last month in which Canada geese were sighted at Fishing Island

\begin{tabular}{|lcl|}
\hline Location & $\begin{array}{c}\text { Giving-up threshold } \\
\left(\mathrm{g} \mathrm{m}^{-2}\right)\end{array}$ & Source \\
\hline Wadden Sea, Denmark & 7.5 & Madsen (1988) \\
Lindisfarne, UK & 5.0 & Percival \& Evans (1997) \\
Limfjorden, Denmark & $1.7-5.9^{\mathrm{a}}$ & Clausen (2000) \\
Fishing Island, USA & 6.7 & Present study \\
${ }^{\mathrm{a} B i o m a s s}$ estimate based on a modeling approach & \\
\hline
\end{tabular}

increased slightly from April to July 2003 at parts of the meadow, eelgrass at Fishing Island clearly did not attain the biomass or percent cover levels seen in a typical summer, indicating that recovery was minimal. Few seeds or seedlings were found, and eelgrass shoot density did not change significantly from April to July 2003, suggesting that neither sexual propagation nor vegetative expansion of shoots contributed to eelgrass recovery. At European Zostera noltii meadows where grazing by brant occurs every winter, $Z$. noltii recovers to typical biomass levels in the summer (Vermaat \& Verhagen 1996, Nacken \& Reise 2000). The difference in recovery between that system and Fishing Island appears to be a result of the feeding behavior of the geese. Brant consume the leaves of $Z$. noltii, leaving the meristem intact (Vermaat \& Verhagen 1996) to re-grow new leaves, whereas Canada geese at Fishing Island typically consumed the lower part of the shoot, including the sheath and the meristem. Once the meristem is removed, eelgrass is unable to produce new leaves, preventing vegetative growth of that shoot.

The Fishing Island case study represents one of the few accounts of eelgrass decline due to Canada goose grazing in the Gulf of Maine region. Other studies in this region have reported how eelgrass availability can affect goose populations (Seymour et al. 2002, Hanson 2004). In contrast, our results show that Canada geese can have a substantial effect on eelgrass populations. In just $3 \mathrm{mo}$, a relatively small number of geese almost completely eliminated the long-standing Fishing Island eelgrass meadow. Unlike many locations where seagrass recovers after a waterfowl grazing event, eelgrass at Fishing Island did not re-establish after Canada geese left the site. The lack of eelgrass recovery will affect the ecology of Fishing Island. The small amount of eelgrass biomass remaining at Fishing Island cannot provide the same functionality as the historical meadow. Further SeagrassNet monitoring has shown a lack of eelgrass recovery and the return of geese to the Fishing
Island meadow during the winterspring of both 2004 and 2005 (Short et al. 2006).

Acknowledgements. We thank B. Smith and E. Robinson at the New Hampshire State Fish and Game Department. Thanks to D. Walker, T. Davis, J. Gaeckle, C. Ochieng, and N. Petit for assistance in the field and laboratory. We thank C. Short for editing and valuable suggestions on the manuscript. Thanks to 3 anonymous reviewers for helpful comments. This work is Jackson Estuarine Laboratory Contribution No. 438.

\section{LITERATURE CITED}

Bak HP (1980) Age populations and biometrics in eelgrass, Zostera marina L. Ophelia 19:155-162

Baldwin JR, Lovvorn, JR (1994) Expansion of seagrass habitat by the exotic Zostera japonica, and its use by dabbling ducks and brant in Boundary Bay, British Columbia. Mar Ecol Prog Ser 103:119-127

Buchsbaum R (1987) The geese and the grass. Sanctuary 27: 7-9

Burdick DM, Short FT, Wolf J (1993) An index to assess and monitor the progression of wasting disease in eelgrass Zostera marina. Mar Ecol Prog Ser 94:83-90

Clausen P (2000) Modelling water level influence on habitat choice and food availability for Zostera feeding brent geese Branta bernicla in non-tidal areas. Wildl Biol 6: $75-87$

Fox AD (1996) Zostera exploitation by brent geese and wigeon on the Exe Estuary, southern England. Bird Study 43:257-268

Gaeckle JL, Short FT (2002) A plastochrone method for measuring leaf growth in eelgrass, Zostera marina L. Bull Mar Sci 71:1237-1246

Ganter B (2000) Seagrass (Zostera spp.) as food for brant geese (Branta bernicla): an overview. Helgol Mar Res 54: $63-70$

Hanson AR (ed) (2004) Status and conservation of eelgrass (Zostera marina) in Eastern Canada. Technical Report Series No. 412. Canadian Wildlife Service, Atlantic Region

Hughes AR, Stachowicz JJ (2004) Genetic diversity enhances the resistance of a seagrass ecosystem to disturbance. Proc Natl Acad Sci USA 101:8998-9002

Jacobs RPWM, den Hartog C, Braster BF, Carriere FC (1981) Grazing of the seagrass Zostera noltii by birds at Terschelling (Dutch Wadden Sea). Aquat Bot 10:241-259

Kenworthy WJ, Thayer GW (1984) Production and decomposition of the roots and rhizomes of seagrasses, Zostera marina and Thalassia testudinum, in temperate and subtropical marine ecosystems. Bull Mar Sci 35:364-379

Madsen J (1988) Autumn feeding ecology of herbivorous wildfowl in the Danish Wadden Sea and the impact of food supplies and shooting movements. Dan Rev Game Biol 13: $2-33$

Moore JE, Colwell MA, Mathis RL, Black JM (2004) Staging of Pacific flyway brant in relation to eelgrass abundance and site isolation, with special consideration of Humboldt Bay, California. Biol Conserv 115:475-486

Nacken M, Reise K (2000) Effects of herbivorous birds on intertidal seagrass beds in the northern Wadden Sea. Helgol Mar Res 54:87-94 
Percival SM, Evans PR (1997) Brent Geese Branta bernicla and Zostera: factors affecting the exploitation of a seasonally declining food resource. Ibis 139:121-128

Percival SM, Sutherland WJ, Evans PR (1996) A spatial depletion model of the responses of grazing wildfowl to the availability of intertidal vegetation. J Appl Ecol 33:979-992

Percival SM, Sutherland WJ, Evans PR (1998) Intertidal habitat loss and wildfowl numbers: applications of a spatial depletion model. J Appl Ecol 35:57-63

Pinnerup SP 1980. Leaf production of Zostera marina L. at different salinities. Ophelia 1:219-224

Portig AA, Mathers RG, Montgomery WI, Govier RN (1994) The distribution and utilization of Zostera species in Strangford Lough, Northern Ireland. Aquat Bot 47:317-328

Seymour NR, Miller AG, Garbary DJ (2002) Decline of Canada geese (Branta canadensis) and common goldeneye (Bucephala clangula) associated with a collapse of eelgrass (Zostera marina) in a Nova Scotia estuary. Helgol Mar Res 56:198-202

Short FT (ed) (1992) The ecology of the Great Bay Estuary, New Hampshire and Maine: an estuarine profile and bibliography. NOAA - Coastal Ocean Program Publ, Durham, NH

Short FT, Burdick DM (1996) Quantifying eelgrass habitat loss in relation to housing development and nitrogen loading in Waquoit Bay, Massachusetts. Estuaries 19:730-739

Short FT, Wolf J, Jones GE (1989) Sustaining eelgrass to manage a healthy ecosystem. Proc 6th Symp Coastal and

Editorial responsibility: Kenneth Heck (Contributing Editor), Dauphin Island, Alabama, USA
Ocean Management. ASCE. July 11-14 Charleston, SC, p 3689-3706

Short FT, McKenzie LJ, Coles RG, Vidler KP (2002) SeagrassNet Manual for Scientific Monitoring of Seagrass Habitat. Queensland Department of Primary Industries, QFS, Cairns

Short FT, Koch E, Creed JC, Magalhaes KM, Fernandez E, Gaeckle J, Rivers DO (2006) SeagrassNet monitoring across the Americas: case studies of seagrass change. PSZN I: Mar Ecol 27:277-289

Tubbs CR, Tubbs JM (1982) Brent geese (Branta bernicla) and their food in the Solent, southern England. Biol Conserv $23: 33-54$

Vermaat JE, Verhagen FCA (1996) Seasonal variation in the intertidal seagrass Zostera noltii Hornem: coupling demographic and physiological patterns. Aquat Bot 52:259-281

Vogel L (1995) Wintering waterfowl on Great Bay. Technical Report No. 2 prepared for NOAA and the New Hampshire Fish and Game Department, Concord. NH

Ward DH, Morton A, Tibbitts TL, Douglas DC, CarreraGonzález E (2003) Long-term change in eelgrass distribution at Bahía San Quintín, Baja California, Mexico, using satellite imagery. Estuaries 26:1529-1539

Wilson UW, Atkinson JB (1995) Black brant winter and spring-staging use at two Washington coastal areas in relation to eelgrass abundance. Condor 97:91-98

Zar JH (1999) Biostatistical analysis, 4th edn. Prentice Hall, Upper Saddle River, NJ

Submitted: November 7, 2005; Accepted: August 15, 2006 Proofs received from author(s): March 1, 2006 